\title{
EFFECT OF FERMENTED Sauropus androgynus LEAVES ON BLOOD LIPID FRACTION AND HAEMATOLOGICAL PROFILE IN BROILER CHICKENS
}

\author{
U. Santoso, Y. Fenita and Kususiyah \\ Faculty of Agriculture, Bengkulu University, \\ Jalan Raya W.R. Supratman, Kandang Limun, Bengkulu 38371A - Indonesia \\ Corresponding E-mail: uripsantoso60@gmail.com
}

Received September 25, 2015; Accepted November 21, 2015

\begin{abstract}
ABSTRAK
Penelitian ini dilakukan untuk mengevaluasi pengaruh daun katuk (Sauropus androgynus) fermentasi terhadap konsentrasi fraksi lipid darah dan profil hematologis pada ayam broiler. Seratus dua belas ekor ayam broiler dikelompokkan ke dalam 7 kelompok perlakuan. Satu kelompok diberi pakan tanpa daun katuk fermentasi sebagai kontrol, dan enam kelompok lainnya diberi pakan yang mengandung daun katuk yang difermentasi oleh Neurospora crassa, Lactobacillus sp. (EM4) atau Saccharomyces cerevisiae pada tingkat $25 \mathrm{~g} / \mathrm{kg}$ atau $50 \mathrm{~g} / \mathrm{kg}$ pakan. Hasil penelitian menunjukkan bahwa perlakuan berpengaruh tidak nyata terhadap kolesterol, high-density lipoprotein cholesterol (HDL-c), low-lipoprotein cholesterol (LDL-c) dan indeks aterogenik, very low-density lipoprotein cholesterol (VLDL-c) dan konsentrasi trigliserida $(\mathrm{P}>0,05)$. Hasil penelitian ini menunjukkan bahwa daun katuk fermentasi secara nyata mempengaruhi red blood count (RBC), white blood count (WBC), packed cell volume $(\mathrm{PCV})$, trombosit dan erythrocyte sedimentation rate $(\mathrm{ESR})(\mathrm{P}<0,05)$, tetapi tidak berpengaruh pada hemoglobin, mean corpuscular hemoglobin $(\mathrm{MCH})$, mean corpuscular hemoglobin concentration (MCHC), dan mean corpuscular volume (MCV). Disimpulkan bahwa daun katuk yang difermentasi oleh Neurospora crassa meningkatkan jumlah trombosit. Di samping itu, daun katuk fermentasi tidak dapat menurunkan konsentrasi trigliserida dan kolesterol darah serta indeks aterogenik pada ayam broiler. Pemberian $50 \mathrm{~g}$ daun katuk yang difermentasi oleh EM4 bersifat racun bagi ayam broiler.
\end{abstract}

Kata kunci: daun katuk fermentasi, fraksi lipid, profil hematologis, ayam broiler

\begin{abstract}
This study was conducted to evaluate effect of fermented Sauropus androgynus leaves on blood lipid fractions and haematological profiles in broilers. One hundred and twelve broilers were distributed to 7 treatment groups. One group was fed diets without Sauropus androgynus leaves as the control, and other six groups were fed Sauropus androgynus leaves fermented by Neurospora crassa, Lactobacillus $s p$. or Saccharomyces cerevisiae at level of $25 \mathrm{~g}$ or $50 \mathrm{~g} / \mathrm{kg}$ diet. Experimental results showed that the treatments had no effect on cholesterol, high-density lipoprotein cholesterol (HDL-c), low-density lipoprotein cholesterol (LDL-c) and atherogenic index, very low-density lipoprotein cholesterol (VLDLc) and triglyceride concentration $(\mathrm{P}>0.05)$. It was shown that fermented Sauropus androgynus leaves significantly affected red blood count (RBC), white blood count (WBC), packed cell volume (PCV), trombosit dan erythrocyte sedimentation rate $(\mathrm{ESR})(\mathrm{P}<0.05)$, but it had no effect on haemoglobin, mean corpuscular hemoglobin $(\mathrm{MCH})$, mean corpuscular hemoglobin concentration $(\mathrm{MCHC})$, dan mean corpuscular volume (MCV). It was concluded that Sauropus androgynus leaves fermented by Neurospora crassa increased trombocyte number. Fermented Sauropus androgynus leaves had no beneficial effect on lowering blood triglyceride and cholesterol concentrations, and atherogenic index in
\end{abstract}


broiler chickens. Feeding 50 g EM4 fermented Sauropus androgynus leaves per kg diet might be toxic for broiler chickens.

Keywords: fermented Sauropus androgynus, lipid fractions, haemotological profiles, broilers

\section{INTRODUCTION}

Rapid increases in the body weight was accompanied by a higher abdominal fat and carcass fat in broiler chickens. This excess fat accumulation was a waste of energy for poultry producers and consumers (Musa et al., 2006). Therefore, the selection of lean breed of broiler chicks become an important value in recent years. However, measuring abdominal fat and carcass fat content for selecting lean broiler chicks required slaughtering broiler and fat analysis which require many facilities and high cost. Therefore, it is required a simple method to predict those values. Experimental results showed that lipid concentration in serum was a good parameter to predict lipid content in animals. Musa et al. (2007) reported that abdominal fat was positively correlated with triglycerides, very low-density lipoprotein (VLDL), and low-density lipoprotein (LDL), and negatively correlated with cholesterol and high-density lipoprotein (HDL) in chickens.

On the other hand, experimental results showed that there is correlation between concentration of blood fat such as cholesterol with the risk of atherosclerosis, heart coronary, stroke and other metabolic diseases (Willett, 2012). This fenomenon could be minimized by feed additive supplementaion. Sauropus androgynus leaves were rich in linolenic acid $(31.75 \%)$, palmitic acid $(12.14 \%)$, chlorophyll $(9.33 \%)$, benzoic acid $(8.58 \%)$ and alkaloid (7.2\%) (Samad et al., 2014) which might be benefit for reducing lipid fractions concentration. Previous study showed that Sauropus androgynus leaves reduced serum cholesterol (Santoso et al., 2010). In additon, it has been shown that Sauropus androgynus leaves and its extract reduced fat contents of meat and egg (Santoso et al., 2005; Subekti, 2007). However, the reduction of fat contents in broiler chicks was still under $25 \%$ which was still had not economic significant in industries (Santoso et al., 2005). Furthermore, Sauropus androgynus leaves tended to lower body weight gain (Santoso and Sartini, 2001). This will decrease the profit of broiler industries because in Indonesia the price of broiler meat is stiil based on body weight rather than carcass quality.
Sauropus androgynus leaves contained antinutritions such as oxalate, saponin, tannin, oligosacharide and inhibit calsium absorption (Santoso, 2014), and caused lung abnormality (Hasyimoto et al., 2013).

To improve the value of Sauropus androgynus leaves, they could be fermented. Fermentation had an important role in improvement of nutritional and functional properties of foods. Cleavage of food proteins by microbial or indigenous proteases yields the bioactive peptides, leading to substantial increases in the biological properties of the food (Steinkraus, 2002). Moreover, fermented food products are a good source of peptides and amino acids (Rajapakse et al., 2005). Fermentation increased nutritional values and feed utuilization in poultry, and protein and soluble protein, and converted protein to peptide and amino acid (Susi, 2012), increased nutrient digestiblity (Chiang et al., 2010), increased the activity of trypsin, lipase, and protease (Feng et al., 2007), improved amino acid balance (Ari et al., 2012; Susi 2012), reduced crude fiber and reduced antinutritions such as trypsin inhibitor (Ari et al., 2012), tannin (Olaniyi dan Mehdizadeh, 2013) and phytic acid (Ari et al., 2012; Olagunju dan Ifesan, 2013), phenol, phytin phosphorus and oxalate (Olagunju dan Ifesan, 2013), saponin (Olaniyi dan Mehdizadeh, 2013), and alkaloid (Shu et al., 2010). Fermentation by Lactobacillus or Saccharomyces cerevisiae (Dordevic et al., 2010) and Bacillus subtilis (Juan dan Chou, 2010) increased antioxidant properties. Experimental results also showed that fermentation increased mineral availability. Furthemore, there is no study of fermented Sauropus androgynus leaves influence on haematological profiles in broiler chickens.

The present study was conducted to evaluate effect of fermented Sauropus androgynus leaves on blood lipid fractions and haematological profiles in broiler chickens. It was hypothesized that feeding fermented Sauropus androgynus leaves reduced blood cholesterol, triglyceride and LDL but increased HDL concentration, whereas haematological profiles were also improved. 


\section{MATERIALS AND METHODS}

\section{Animals}

One hundred and twelve broiler chicks were obtained from commercial hatchery, and all feedstuffs were purchased from commercial plants. Chemicals used for analysis were of analytical grade. The experimental diets contained protein 19\% and Metabolizable Energy (ME) $3,150 \mathrm{kcal} / \mathrm{kg}$. The composition of experimental diet was published elsewhere (Santoso et al., 2015). From 1 to 14 days of age, supplemental heat was provided. Broiler chickens were maintained on the floor in a house under continuous lighting.

\section{Fermented Sauropus androgynus Treatments}

At 15 days of age, one hundred and twelve broiler chicks were selected and distributed to 7 treatment groups with 4 replicates of 4 broiler chicks each as follows: 1) Broiler were fed diets without Sauropus androgynus leaves as the control (P0); 2) Broilers were fed diets contained 25 g Sauropus androgynus leaves fermented by Neurospora crassa/kg diet (P1); 3) Broilers were fed diets contained $50 \mathrm{~g}$ Sauropus androgynus leaves fermented by Neurospora crassa $/ \mathrm{kg}$ diet (P2); 4) Broilers were fed diets contained $25 \mathrm{~g}$ Sauropus androgynus leaves fermented by Lactobacillus sp (EM4)/kg diet (P3); 5) Broilers were fed diets with $50 \mathrm{~g}$ Sauropus androgynus leaves fermented by Lactobacillus $s p$ (EM4) $/ \mathrm{kg}$ diet (P4); 6) Broilers were fed diets contained 25 $\mathrm{g}$ Sauropus androgynus leaves fermented by Saccharomyces cerevisiae $/ \mathrm{kg}$ diet (P5); 7) Broilers were fed diets contained $50 \mathrm{~g}$ Sauropus androgynus leaves fermented by Saccharomyces cerevisiae/kg diet (P6).

Feed and water were provided ad libitum. Broiler chickens were weighed individually on a weekly basis, and feed consumption was recorded daily.

\section{Sampling and Data Analysis}

At the end of experiment ( 35 days of age), 4 broiler chickens in each treatment group were selected and blood samples were collected by puncturing wing vein using $3 \mathrm{ml}$ syringe and collected to bottles without anticoagulant agent. Immediately after blood collection, the sample bottles were gently shaken to prevent lysing of the blood (Ekeh et al., 2010).

The packed cell volume (PVC) was determined by the micro haematocrit method (Coles, 1986). The haemoglobin concentration was determined using the cyanmethemoglobin method while the erythrocyte (red blood count, RBC) was carried out using the haemocytometer method (Schalm et al.,1975). The thrombocyte count was determined using the Ress-Ecker method (Brown, 1976) and the total leukocyte (white blood count, WBC) was determined using haemocytometer method (Schalm et al., 1975) while the differential leukocyte count was determined using the Leishman technique (Coles, 1986).

To obtain the plasma, blood samples were collected to bottle with anticoagulant agent, and centrifuged at $3000 \mathrm{rpm}$. Blood serum obtained were then analyzed for triglyceride, cholesterol, high-density lipoprotein cholesterol (HDL-c) and low-density lipoprotein cholesterol (LDL-c).

Total cholesterol and LDL-c were determined by the method of Kulkami (2006) and triglyceride concentrations were determined by the method of Fossati and Prencipe (1982). Very low-density lipoprotein cholesterol (VLDL-c) was calculated by the following equation:

VLDL-c $=$ cholesterol $-($ HDL-c + LDL-c $)$

In order to predict the risk of atherosclerosis occurences, atherogenic index was calculated by the equation:

Atherogenic index $=[($ Total cholesterol HDL-c)]/(HDL-c)

Internal organs (liver, heart, pankreas, intestine, gizzard, spleen) were removed and weighed, and then calculated by the equation:

Internal organ $(\%)=$ internal organ weight/live wight x $100 \%$

Toxicity score was calculated by the equation:

Toxicity $(\%)=$ liver + spleen weights/live weight $x 100 \%$

\section{Statistical Analysis}

All data were subjected to analysis of variance (Toutenburg and Shalabh, 2009) and if it was significantly different it was further tested by Duncan's multiple range test.

\section{RESULTS AND DISCUSSION}

\section{Lipid Fraction Concentrations}

Experimental results showed that the treatments had no effect on blood cholesterol, HDL-c, LDL-c, atherogenic index, VLDL-c and triglyceride concentration $(\mathrm{P}>0.05)$ as shown in 
Table 1. Lipid Fraction Concentration in Plasma of Broiler Chickens

\begin{tabular}{lrrrrrrrr}
\hline & \multicolumn{1}{c}{ P0 } & \multicolumn{1}{c}{ P1 } & \multicolumn{1}{c}{ P2 } & \multicolumn{1}{c}{ P3 } & \multicolumn{1}{c}{ P4 } & \multicolumn{1}{c}{ P5 } & P6 & SD \\
\hline Cholesterol & 113.8 & 118.5 & 116.5 & 114.5 & 123.3 & 114.0 & 126.3 & $15.1^{\mathrm{ns}}$ \\
Triglyceride & $18.0^{\mathrm{a}}$ & 26.0 & 39.8 & 26.8 & 21.8 & 23.8 & 28.3 & $15.7^{\mathrm{ns}}$ \\
HDL-c & 70.5 & 68.8 & 70.3 & 66.0 & 69.5 & 67.3 & 74.3 & $9.0^{\mathrm{ns}}$ \\
LDL-c & 39.3 & 42.8 & 38.0 & 42.8 & 48.8 & 40.3 & 45.8 & $9.0^{\mathrm{ns}}$ \\
VLDL-c & 4.0 & 6.9 & 8.2 & 5.7 & 5.0 & 6.4 & 6.2 & $3.5^{\mathrm{ns}}$ \\
Atherogenic index & 0.61 & 0.72 & 0.66 & 0.73 & 0.77 & 0.69 & 0.70 & $0.11^{\mathrm{ns}}$ \\
\hline
\end{tabular}

$\mathrm{P} 0=$ control; $\mathrm{P} 1=$ diets with $2.5 \%$ Sauropus androgynus leaves fermented by Neurospora crassa $; \mathrm{P} 2=$ diets with 5\% Sauropus androgynus leaves fermented by Neurospora crassa; P3= diets with $2.5 \%$ Sauropus androgynus leaves fermented by Lactobacillus sp (EM4); P4= diets with 5\% Sauropus androgynus leaves fermented by Lactobacillus sp (EM4); P5= diets with 2.5\% Sauropus androgynus leaves fermented by Saccharomyces cerevisiae; P6= diets with 5\% Sauropus androgynus leaves fermented by Saccharomyces cerevisiae.

Table 1. This finding did not agree with the observation of Kamalia et al. (2014) who found that supplementation of Sauropus androgynus leaves at level 1-3\% in broiler chicken diets increased HDL-c and tended to decrease LDL-c. It was unkown why fermentation did not change blood lipid fractions of broiler chickens. Although fermented Sauropus androgynus did not reduce LDL-c and cholesterol it might still be benefit for broiler chickens, because Sauropus androgynus leaves had a high level of antioxidant and antiinflammatory activities (Madhu et al., 2014). This antioxidant property of these leaves would inhibit LDL-c oxidation and therefore it might inhibit atherosclerotic lesion development (Koyama et al., 2006).

The present study was in contrary with the observation Kamalia et al. (2014), Zain (2011) and Santoso et al. (2005) who reported that supplementation of unfermented Sauropus androgynus leaves extract reduced total cholsterol, triglyceride, and LDL-c but increased HDL-c concentrations in serum of broiler chickens. Fermentation might reduce antinutritions such as tannin and saponin (Olaniyi dan Mehdizadeh, 2013), and alkaloid (Shu et al., 2010). It was konwn that these compounds had antilipid properties (Afrose et al., 2010; Santoso et al., 2010). Therefore, no beneficial effect of fermented Sauropus androgynus leaves might partly be caused by the reduction of these antilipid compounds.

Various studies showed that lipid fraction concentration of broilers varied. Triglyceride, cholesterol, HDL-c, LDL-c and VLDL-c ranged from 19.09 to $<150 \mathrm{mg} / \mathrm{dL}, 52-157.8 \mathrm{mg} / \mathrm{dL}$, $>22-118.15 \mathrm{mg} / \mathrm{dL}, 35.56-<130 \mathrm{mg} / \mathrm{dL}$, and 3.8224.06, respectively (Basmacioglu and Ergul, 2005; Musa et al., 2007; Prasad et al., 2009; Daneshyar et al., 2011). It appeared that age and strain of broiler chickens affected lipid fraction concentrations. This study, therefore, showed that lipid fraction concentrations in the plasma of broiler chickens were still in normal range.

\section{Haematological Profile}

Table 2 presents haematological profile of broiler chickens. Results showed that fermented Sauropus androgynus leaves significantly affected red blood count (RBC), white blood count (WBC), PCV, erythrocyte sedimentation rate (ESR) and thrombocyte $(\mathrm{P}<0.05)$, but it had no effect on haemoglobin $(\mathrm{Hb}), \mathrm{MCH}, \mathrm{MCV}$ and $\mathrm{MCHC}(\mathrm{P}>0.05)$. WBC was higher in $\mathrm{P} 4$ as compared to other treatment groups. Although it was not significantly different, $\mathrm{Hb}$ in P2, P3, P5 and $\mathrm{P} 6$ tended to be increased as compared to $\mathrm{P} 0$. $\mathrm{PCV}$ of $\mathrm{P} 3$ was higher than $\mathrm{P} 0, \mathrm{P} 1, \mathrm{P} 2$ and $\mathrm{P} 4$, whereas $\mathrm{RBC}$ of $\mathrm{P} 3$ was higher than $\mathrm{P} 1 \quad(\mathrm{P}<0.05)$ but not significant with other treatment groups. ESR of P1 was the highest, whereas thrombocyte was higher in $\mathrm{P} 1$ and $\mathrm{P} 2$ as compared with $\mathrm{P} 0, \mathrm{P} 4$ and $\mathrm{P} 6(\mathrm{P}<0.05)$.

Higher thrombocyte in Neurospora crassa fermented Sauropus androgynus leaves - but still in normal range - indicated that immunity system 
Table 2. Haematological Profile of Broiler Chickens

\begin{tabular}{lcccccccc}
\hline & P0 & P1 & P2 & P3 & P4 & P5 & P6 & SD \\
\hline RBC $\left(\times 10^{6} / \mathrm{mm}^{3}\right)$ & $2.63^{\mathrm{ab}}$ & $2.40^{\mathrm{b}}$ & $2.61^{\mathrm{ab}}$ & $2.85^{\mathrm{a}}$ & $2.56^{\mathrm{ab}}$ & $2.74^{\mathrm{ab}}$ & $2.72^{\mathrm{ab}}$ & $0.16^{*}$ \\
WBC $\left(\times 10^{3} / \mathrm{mm}^{3}\right)$ & $26.55^{\mathrm{b}}$ & $25.63^{\mathrm{b}}$ & $26.54^{\mathrm{b}}$ & $27.12^{\mathrm{b}}$ & $36.06^{\mathrm{a}}$ & $27.00^{\mathrm{b}}$ & $27.10^{\mathrm{b}}$ & $1.0^{*}$ \\
Lymphocite, \% & 96.0 & 97.0 & 96.0 & 96.0 & 93.0 & 96.0 & 96.0 & $2.8^{\mathrm{ns}}$ \\
Thrombocite, x 10 $\left./ \mathrm{mm}^{3}\right)$ & $2.25^{\mathrm{b}}$ & $5.25^{\mathrm{a}}$ & $6.25^{\mathrm{a}}$ & $3.75^{\mathrm{ab}}$ & $2.25^{\mathrm{b}}$ & $3.50^{\mathrm{ab}}$ & $2.0^{\mathrm{b}}$ & $1.6^{*}$ \\
PCV, \% & $33.75^{\mathrm{b}}$ & $32.25^{\mathrm{b}}$ & $33.00^{\mathrm{b}}$ & $37.75^{\mathrm{a}}$ & $32.75^{\mathrm{b}}$ & $35.25^{\mathrm{ab}}$ & $34.75^{\mathrm{ab}}$ & $1.5^{*}$ \\
Haemoglobin, g/ml & 10.4 & 9.88 & 10.48 & 11.95 & 9.95 & 11.13 & 10.83 & $1.1^{\mathrm{ns}}$ \\
MCH, pg & 39.25 & 40.75 & 39.75 & 41.75 & 38.5 & 40.0 & 39.5 & $2.0^{\mathrm{ns}}$ \\
MCV, fl & 129.00 & 135.50 & 128.75 & 133.75 & 129.25 & 129.25 & 128.75 & $4.8^{\mathrm{ns}}$ \\
MCHC, \% & 30.0 & 30.0 & 30.5 & 31.0 & 29.75 & 30.75 & 30.25 & $0.9^{\mathrm{ns}}$ \\
ESR, mm/hour & $3.25^{\mathrm{c}}$ & $8.25^{\mathrm{a}}$ & $3.25^{\mathrm{c}}$ & $4.0^{\mathrm{c}}$ & $5.0^{\mathrm{b}}$ & $5.0^{\mathrm{b}}$ & $4.5^{\mathrm{ab}}$ & $1.5^{*}$ \\
\hline
\end{tabular}

Note: see Table 1.

Table 3. Internal Organ Weights in Broiler Chickens

\begin{tabular}{lllllllll}
\hline & P0 & P1 & P2 & P3 & P4 & P5 & P6 & SD \\
\hline Liver & 2.14 & 2.08 & 2.20 & 2.28 & 2.85 & 2.13 & 2.18 & $0.45^{\mathrm{ns}}$ \\
Heart & 0.40 & 0.35 & 0.41 & 0.39 & 0.46 & 0.37 & 0.36 & $0.08^{\mathrm{ns}}$ \\
Spleen & 0.14 & 0.17 & 0.15 & 0.15 & 0.19 & 0.10 & 0.12 & $0.06^{\mathrm{ns}}$ \\
Intestine & 3.27 & 2.86 & 3.18 & 3.28 & 3.86 & 3.13 & 3.12 & $0.49^{\mathrm{ns}}$ \\
Gizzard & 1.83 & 1.93 & 2.06 & 2.03 & 2.21 & 1.84 & 1.78 & $0.24^{\mathrm{ns}}$ \\
Pankreas & 0.29 & 0.30 & 0.33 & 0.26 & 0.45 & 0.28 & 0.30 & $0.08^{\mathrm{ns}}$ \\
Toxicity & $2.27^{\mathrm{b}}$ & $2.25^{\mathrm{b}}$ & $2.36^{\mathrm{b}}$ & $2.43^{\mathrm{b}}$ & $3.04^{\mathrm{a}}$ & $2.23^{\mathrm{b}}$ & $2.30^{\mathrm{b}}$ & $0.47^{*}$ \\
Mortality & 0.00 & 0.00 & 0.00 & 0.00 & 1.00 & 0.00 & 0.00 & \\
\hline
\end{tabular}

Note: see Table 1.

was improved. Thrombocytes were found to phagocytose bacteria. Furthermore, oxidative burst activity was generated upon challenge of thrombocytes with various Salmonella strains, $E$. coli, three other bacterial species, and zymosan A (Wigley et al., 1999). Therefore, thrombocytes might play an important role in innate immunity to bacteria in the chicken (Farzana, 2014; Wigley et al., 1999).

Suprayogi et al. (2007) found that fermented
Sauropus androgynus leaves extract tended to increase RBC, PCV, $\mathrm{Hb}$ and WBC. Furthermore, they stated that papaverine and polyunsaturated fatty acids contained in Sauropus androgynus leaves may be as precursors in the eicosanoids biosynthesis such as prostaglandin, prostacycline, thromboxane, lipoxines dan leukotrienes. Adesua and Onibi (2014) reported that inclusion of fermented wheat bran to broiler diets did not change $\mathrm{PCV}, \mathrm{Hb}$ and $\mathrm{RBC}$, whereas Adeyemi et 
al. (2008) showed no change in PCV, RBC and $\mathrm{Hb}$ was observed with a decreased in WBC. A higher $\mathrm{WBC}$ in $\mathrm{P} 4$ might relate to toxicity indication. This prediction was supported by higher toxicity score, mortality and the tendency of higher liver and spleen weight.

An increase in ESR of P1, P4 and P5 might be the result of increase tendency in serum LDL concentration (Khan and Zafar, 2005), as this lipoprotein got coated on the surface of $\mathrm{RBC}$ therefore increasing its ESR.

The average number of $\mathrm{RBC}$ in chicken range from $2.0 \times 10^{6} / \mathrm{mm}^{3}$ to $3.5 \times 10^{6} / \mathrm{mm}^{3}$ (Onibi et al., 2011; Swenson,1984; Smith and Mangkoewidjojo, 1988). Normal value of hemoglobin in chicken range from $6.5-13.0 \mathrm{~g} / \mathrm{mL}$ (Onibi et al., 2011; Orawan and Aengwanich, 2007; Swenson, 1984), PCV range from 22-43\% (Onibi et al., 2011; Orawan and Aengwanich, 2007; Smith and Mangkoewidjojo, 1988), WBC range from 11.4-30 x 103/. $\mathrm{mm}^{3}$ (Swenson, 1984; Orawan and Aengwanich, 2007); lymphocyte range from 24-84\% (Smith and Mangkoewidjojo, 1988; Orawan and Aengwanich, 2007); thrombocyte range from 3-33 $\times 10^{9} / 1$ (Smith and Mangkoewidjojo, 1988), erythrocyte sedimentation rate (ESR) range from 3.0-12 mm per hour, MCV 132.21 fl (Orawan and Aengwanich, 2007), MCH 33.0-47.0 pg (Orawan and Aengwanich, 2007) and MCHC 26.35 (Orawan and Aengwanich, 2007). Based on the above data it was concluded that the haemtological profiles of broiler chickens in this study were still in normal range.

\section{Internal Organ Weights and Toxicity Score}

Experimental results showed that fermented Sauropus androgynus leaves had no effect on liver, heart, spleen, intestine, gizzard, and pankreas $(\mathrm{P}>0.05)$, whereas toxicity was significantly different $(\mathrm{P}<0.05)$ as shown in Table 3. Toxicity was higher in $\mathrm{P} 4$ than $\mathrm{P} 0, \mathrm{P} 1, \mathrm{P} 2, \mathrm{P} 3$, $\mathrm{P} 5$ and P6. Although it was not significantly different P4 had the highest internal organ weight including liver and spleen. It appear that feeding 50 g EM4 fermented Sauropus androgynus leaves $/ \mathrm{kg}$ diet had toxic properties as indicated by higher toxicity score and mortality in this group. This prediction was supported by the higher WBC in this treatment group. Adeyemi et al. (2008) reported that inclusion of fermented cassava root to broiler diet did not change relative liver, spleen and gizzard weights but it increased heart and pankreas weights.

\section{CONCLUSION}

Fermented Sauropus androgynus leaves had no beneficial effect on lowering cholesterol and triglyceride concentrations, and atherogenic index. Although fermented Sauropus androgynus did not reduce plasma LDL-c and cholesterol concentrations it might still be beneficial for broiler chickens, because a high level of antioxidant and anti-inflammatory activities in Sauropus androgynus leaves might inhibit LDL-c oxidation and therefore it might inhibit atherosclerotic lesion development. Neurospora crassa fermented Sauropus androgynus leaves increased the number of thrombocyte. Broiler chicken fed 25 g EM4 fermented Sauropus androgynus leaves $/ \mathrm{kg}$ diet had higher PCV and $\mathrm{RBC}$, whereas broiler chicken fed $50 \mathrm{~g}$ EM4 fermented Sauropus androgynus leaves $/ \mathrm{kg}$ diet had higher WBC. Feeding 50 g EM4 fermented Sauropus androgynus leaves $/ \mathrm{kg}$ diet might be toxic for broiler chickens.

\section{ACKNOWLEDGMENTS}

The present experiment was supported by Directorate General Higher Education, Ministry of Research, Technology and Higher Education under contract number: 349/UN30/15/LT/2015. The authors also thank to LPPM Universitas Bengkulu which supported this research.

\section{REFERENCES}

Adesua, A. A. and G. E. Onibi. 2014. Growth Performance, Haematology and Meat Quality Of Broiler Chickens Fed Rumen Liquor-Fermented Wheat Bran-Based Diets. Jordan J. Agric. Sci. 10:725-735.

Adeyemi, O. A., D. Eruvbetine, T. Oguntona, M. Dipeolu and J. A. Agunbiade. 2008. Feeding broiler chicken with diets containing whole cassava root meal fermented with rumen filtrate. Arch. Zootec. 57:247-258.

Afrose, S., M. S. Hossain and H. Tsujii. 2010. Effect of dietary karaya saponin on serum and egg yolk cholesterol in laying hens. Br. Poultry Sci. 51:797-804.

Ari, M. M., B. A. Ayanwale, T. Z. Adama and E. A. Olatunji. 2012. Effects of different fermentation methods on the proximate composition, amino acid profile and some 
antinutritional factors (ANFs) in soyabeans (Glycine max). Fermentation Technol. Bioengineering 2:6-13.

Basmacioglu, H. and M. Ergul. 2005. Research on the factor affecting cholesterol content and some other characteristics of eggs in laying hens. Turk. J. Vet. Anim . Sci. 29: 157-164

Brown, B. A. 1976. Direct Methods for platelet counts, Rees and Ecker method. In: Brown, B. A. (Ed.).Haematology: Principles and Procedures. Second Edition, Lea and Febiger, Philadelphia. pp: 101-103.

Chiang, G., W. Q. Lu, X. S. Piao, J. K. Hu, L. M. Gong and P. A. Thacker. 2010. Effects of feeding solid-state fermented rapeseed meal on performance, nutrient digestibility, intestinal ecology and intestinal morphology of broiler chickens. Asian-Aust. J. Anim. Sci. 23: 263-271.

Coles, E. H. 1986. Veterinary Clinical Pathology. Fourth Edition, WB Sanders Company, Philadelphia.

Daneshyar, M., M. A. Ghandkanlo, F. S. Bayeghra, F. Farhangpajhoh and M. Aghaei. 2011. Effects of dietary turmeric supplementation on plasma lipoproteins, meat quality and fatty acid composition in broilers. South African J. Anim. Sci. 41:420428.

Dordevic, T. M., S. S. Siler-Marinkovic, and S. I. Dimitrijevic-Brankovic. 2010. Effect of fermentation on antioxidant properties of some cereals and pseudo cereals. Food Chem. 119:957-963

Ekeh, F. N., Ekechukwu, N. E., C. I. Atama and I. C. Atta. 2010. Haematology profile of albino rats given feed and water contaminated with varied concentrations of used engine oil. Anim. Res. Int. 7:1222-1235.

Farzana, F. 2014. The Avian Thrombocyte is a Specialized Immune Cell. Dissertation. Paper 1289. Clemson University Tiger Prints.

Feng, J., X. Liu, Z. R. Xu, Y. Z. Wang and J. X. Liu. 2007. Effects of fermented soybean meal on digestive enzyme activities and intestinal morphology in broilers. Poultry Sci. 86:1149-1154.

Fossati, P. and L. Prencipe. 1982. Serum triglycerides determined colorimetrically with an enzyme that produces hydrogen peroxide Clinical Chem. 28:2077-2080

Hashimoto, I., K. Imaizumi, N. Hashimoto, H. Furukawa, Y. Noda, T. Kawabe, T. Honda, T.
Ogawa, M. Matsuo, N. Satoruito, M. Sato, M. Kondo, K. Shimokata and Y. Hasegawa. 2013. Aqueous fraction of Sauropus androgynus might be responsible for bronchiolitis obliterans. Respirology 18:340347.

Juan, M. Y. and C. C. Chou. 2010. Enhancement of antioxidant activity, total phenolic and flavonoid. content of black soybeans by solid state fermentation with Bacillus subtilis BCRC 14715. Food Microbiol. 27:586-91.

Kamalia, A. Mujenisa and A. Natsir. 2014. Pengaruh penambahan berbagai level tepung daun katuk (Sauropus androgynus) terhadap kolesterol, trigliserida, LDL dan HDL darah broiler. Buletin Nutrisi dan Makanan Ternak 10: $12-18$.

Khan, T. A. and F. Zafar. 2005. Haematological study in response to varying doses of estrogen in broiler chicken. Int. J. Poultry Sci. 4:748-751.

Koyama, N., K. Kuribayashi, T. Seki, K. Kobayashi, Y. Furuhata, K. Suzuki, H. Arisaka, T. Nakano, Y. Amino and K. Ishi. 2006. Serotonin derivatives, major safflower (Carthamus tinctorius L.) seed antioxidants, inhibit low-density lipoprotein (LDL) oxidation and atherosclerosis in apolipoprotein E-deficient mice. J. Agric. Food Chem. 54: 4970-4976.

Kulkami, K. R. 2006. Cholesterol profile measurement by vertical auto profile method. Clinics in Laboratory Medicine. 26: 787-802.

Madhu, C. S., H. M. G. Manukumar and P. Basavaraju. 2014. New-vista in finding antioxidant and anti-inflammatory property of crude protein extract from Sauropus androgynus leaf. Acta Sci. Pol., Technol. Aliment. 13: 375-383.

Musa, H. H., G. H. Chen, K. H. Wang, B. C. Li, D. M. Mekki, J. T. Shu and H. P. Ju. 2006. Relation between serum cholesterol level, lipoprotein concentration and carcass characteristics in genetically lean and fat chickens breed. J. Biol. Sci. 6:616-620

Musa, H. H., G. H. Chen, J. H. Cheng and G. M. Yousif. 2007. Relation between abdominal fat and serum cholesterol, triglycerides, and lipoprotein concentrations in chicken Breeds. Turk. J. Vet. Anim. Sci. 31:375-379

Olagunju, A. I. and B. O. T. Ifesan. 2013. Changes in nutrient and antinutritional contents of 
sesame seeds during fermentation. J. Microbiol. Biotechnol. Food Sci. 2:24072410 .

Olaniyi, L. O. and S. Mehhizadeh. 2013. Effect of Traditional Fermentation as a Pretreatment to Decrease the Antinutritional Properties of Rambutan Seed (Nephelium lappaceum L.). International Conference on Food and Agricultural Sciences IPCBEE Vol.55 (2013). IACSIT Press, Singapore.

Onibi, G. E., A. O. Bobadoye and O. R. Folorunso. 2011. Haematological indices, serum cholesterol and meat quality of broiler chickens fed diets with palm oil sludge substituting maize. Agric. Biol. J. N. Am. 2: 552-558.

Orawan, C. and W. Aengwanich. 2007. Blood cell characteristics, hematological values and average daily gained weight of Thai Indigenous, Thai Indigenous Crossbred and broiler chickens. Pakistan J. Biol. Sci. 10:302-309

Prasad, R., M. K. Rose, M. Virmani, S. L. Garg and J. P. Puri. 2009. Lipid profile of chicken (Gallus domesticus) in response to dietary supplementation of garlic (Allium sativum). Int. J. Poult. Sci. 8:270-276

Rajapakse, N., E. Mendis, W. K. Je. J. Y. Jung and S. K. Kim. 2005. Purification of a radical scavenging peptide from fermented mussel sauce and its antioxidant properties. Food Res. Int. 38:175-182.

Samad, A. P. A., U. Santoso, M. C. Lee and F. H. Nan. 2014. Effects of dietary katuk (Sauropus androgynus L. Merr.) on growth, non-specific immune and diseases resistance against Vibrio alginolyticus infection in grouper Epinephelus coioides. Fish Shellfish Immunol. 30:582-589.

Santoso, U. 2014. Katuk, Tumbuhan Multikhasiat. Badan Penerbit Fakultas Pertanian Unib, Bengkulu.

Santoso, U., Y. Fenita, Kususiyah and I. G. N. G. Bidura. 2015. Effect of Fermented Sauropus androgynus Leaves on Meat Composition, Amino Acid and Fatty Acid Compositions in Broiler Chickens. Pak. J. Nutr. 14: 799-807

Santoso, U. and Sartini. 2001. Reduction of fat accumulation in broiler chickens by Sauropus androgynus (Katuk) leaf meal supplementation. Asian-Aust. J. Anim. Sci. 14:346-350.

Santoso, U., J. Setianto and T. Suteky. 2005. Effect of Sauropus androgynus (katuk) extract on egg production and lipid metabolism in layers. Asian-Aust. J. Anim. Sci.18:364-369.

Santoso, U., T. Suteky and Y. Fenita. 2010. Effects of supplementation of alkaloid and non alkaloid from Sauropus androgynus leaves on egg production and lipid profil in layer chicken. J. Anim. Prod. 12:184-189.

Schalm, O. W., N. C. Jain and E. J. Carroll. 1975. Veterinary Haemotology. Third Edition, Lea and Febiger, Philadelphia.

Shu, S. J., L. Baining, T. Pingfang, L. Qiang, Z. Youxi and G. Xizhen. 2010. Effect of microbial fermentation on the extraction of alkaloids from radix aconiti and aconite. J. Beijing University Chem. Technol. (Natural Science Ed.). 2010-3. (http://en.cnki.com.cn/ Article_en/CJDTOTAL-BJHY201003019. htm.)

Smith, J. B. and S. Mangkoewidjojo,1988. Pemeliharaan, Pembiakan dan Penggunaan Hewan Percobaan di Daerah Tropis. Universitas Indonesia, Jakarta.

Steinkraus, K. H., 2002. Fermentations in world food processing. Comp. Rev. Food Sci. Food Safety. 1:23-32.

Subekti, S. 2007. Komponen Sterol dalam Ekstrak Daun Kotok (Sauropus androgynus) dan Hubungannya dengan Sistem Reproduksi Puyuh. Dissertation, Bogor Agricultural University, Bogor.

Suprayogi, A., S. S. Aryani, N. Kusumorini, Evrieolita and E. Pantina. 2007. The Influence of fermented and non-fermented Sauropus androgynus (L.) merr. leaves extract on the hematopoiesis in the postnatal mice. Six-University Internasional Symposium, IPB, IICC-Bogor, 4-6 Sept 2007. http://xa.yimg.com/kq/groups/12370 038/2037708508/name/agik-fkh-ipb.

Susi. 2012. Komposisi kimia dan asam amino pada tempe kacang Nagara. Agroscientiae 19:28-36.

Swenson, M. J. 1984. Duke's Physiology of Domestic Animals. 10 ${ }^{\text {th }}$ Edition. Publishing Assocattes a Division of Cornell University. Ithaca and London.

Toutenburg, H. and H.T. Shalabh, 2009. Statistical Analysis of Designed Experiments. $3^{\text {rd }}$ ed. Springer Science+Business Media, LLC. New York, Dordrecht, Heidelberg, London.

Willet, W.C. 2012. Dietary fats and coronary hear disease. I. Int. Med. 272:13-24.

Wigley, P., S. D. Hulme and P. A. Barrow. 1999. 
Phagocytic and oxidative burst activity of chickenthrombocytes to Salmonella, Escherichia coli and other bacteria. Avian Pathol. 28:567-572.

Zain, B. 2011. Pengaruh penggunaan ekstrak daun katuk minyak ikan lemuru dan vitamin $\mathrm{E}$ terhadap performans dan kualitas daging ayam broiler. Jurnal Sain Peternakan Indonesia. 6:89-95. 